\title{
Validitas pengembangan modul pembelajaran berbasis project based learning pada mata pelajaran teknologi informasi dan komunikasi
}

\author{
Eka Khairani $^{1^{*}}$, Hasan Maksum ${ }^{2}$, Fahmi Rizal $^{3}$, Muhammad Adri $^{1}$ \\ ${ }^{1}$ Pendidikan Teknik Informatika, Universitas Negeri Padang, Indonesia \\ ${ }^{2}$ Pendidikan Otomotif, Universitas Negeri Padang, Indonesia \\ ${ }^{3}$ Pendidikan Teknil Sipil dan Bangunan, Universitas Negeri Padang, Indonesia
}

\section{Article Info \\ Article history: \\ Received Des $12^{\text {th }}, 2021$ \\ Revised Jan $20^{\text {th }}, 2022$ \\ Accepted Feb $3^{\text {th }}, 2022$}

\section{Keyword:}

Modul

Project based learning

TIK

Validitas

\begin{abstract}
Inovasi dan pengembangan proses pembelajaran dipandang sebagai proses partisipatif yang melibatkan manajemen, seluruh komunitas sekolah termasuk pemangku kepentingan, yang dapat menciptakan ide-ide baru dalam penyelenggaraan pendidikan Suatu pembelajaran yang menarik dan mandiri membutuhkan suatu media yang bisa merangsang minat dan ketertarikan siswa untuk mengikuti pembelajaran tersebut, terutama pembelajaran daring yang tentunya sangat membosankan bagi siswa karena hanya berkutat dengan benda mati tanpa ada interaksi dengan guru secara langsung. Penelitian ini bertujuan untuk menghasilkan Modul Project Based Learning yang dirancang sebagai alternatif media pembelajaran. Metode dalam penelitian ini menggunakan Model ADDIE dengan prosedur pengembangan Borg And Gall, yaitu tahap Analisis, Defenisi, Design, Implementation dan Evaluation. Hasil yang diperoleh dari penelitian pengembangan ini: Validitas E-learning Berbasis Project Based Learning dinyatakan valid pada aspek media dengan nilai 0,902 dan aspek materi dengan nilai 0,842. Berdasarkan temuan penelitian ini disimpulkan bahwa E-learning Berbasis Project Based learning dinyatakan valid untuk digunakan sebagai alternatif modul pembelajaran Project Based Learning di SMPN 9 Padang.
\end{abstract}

(C) 2022 The Authors. Published by IICET.

This is an open access article under the CC BY-NC-SA license

(https://creativecommons.org/licenses/by-nc-sa/4.0

\section{Corresponding Author:}

Khairani, E.,

Pendidikan Teknik Informatika, Universitas Negeri Padang, Indonesia

Email:3k4hasbi@gmail.com

\section{Pendahuluan}

Pada masa Pandemi sekarang ini, guru harus bisa menggunakan ICT dan memodifikasi metode sehingga materi akan lebih mudah di serap oleh anak. Pada kenyataannnya, saat pada pandemic dan stay at home, banyak sekali siswa yang mengeluh karena tugas yang diberikan, padahal mereka belum diajarkan, anak dituntut untuk memahami materi tanpa belajar secara langsung dengan guru, sehingga dengan kondisi ketidakfahaman anak, anak akan malas mengerjakannnya. Pembelajaran yang dilakukan di SMPN 9 di kota Padang awalnya pemberian tugas melalui aplikasi whatsap.

Inovasi dan pengembangan proses pembelajaran dipandang sebagai proses partisipatif yang melibatkan manajemen, seluruh komunitas sekolah termasuk pemangku kepentingan, yang dapat menciptakan ide-ide baru dalam penyelenggaraan pendidikan. Lembaga pendidikan dengan budaya inovasi mendukung tim manajemen untuk menggunakan kemampuan sumber daya internal dan eksternal untuk meningkatkan 
kualitas lulusannya. Salah satu model pembelajaran yang dikatakan penting untuk dibuat dan dikembangkan dalam menghadapi krisis adalah penerapan manajemen proyek atau PjBL. Dimana, pembelajaran berbasis proyek (PjBL) adalah model pembelajaran yang mengharuskan guru dan atau peserta didik untuk mengembangkan pertanyaan penuntun. Karena setiap mereka memiliki gaya belajar yang berbeda, pendekatan pembelajaran ini memberikan mereka kesempatan untuk mengeksplorasi konten atau materi menggunakan media yang berbeda yang bermakna bagi diri mereka sendiri dan untuk mempraktikkan pengalaman kolaboratif. Hal ini memungkinkan setiap peserta didik untuk akhirnya dapat menjawab pertanyaan penuntun.

Pembelajaran menurut model PjBL memiliki dampak edukatif yang diharapkan dapat meningkatkan prestasi akademik peserta didik dan berdampak pada soft skill yang dapat menciptakan interaksi yang baik antar peserta didik, sehingga menciptakan kondisi yang kondusif bagi peserta didik. (1) meningkatkan kepositifan materi pembelajaran, (2) sangat bagus untuk meningkatkan prestasi akademik peserta didik, (3) dapat meningkatkan keterikatan peserta didik karena semua anggota tim sama-sama bertanggung jawab atas penguasaan materi, (4) dapat meningkatkan kemampuan komunikasi peserta didik, (5) dapat meningkatkan minat belajar, dan (6) meningkatkan kompetisi yang sehat untuk penghargaan tim. Meningkatkan motivasi belajar melalui reward, yang akan memberikan kesempatan belajar seluas-luasnya melalui kegiatan belajar. Langkah-langkah implementasi modul berdasarkan model pembelajaran $\mathrm{PjBL}$ ini sangat perlu dikembangkan untuk menjadi model pembelajaran PjBL yang valid, praktis dan efektif pada mata pelajaran TIK untuk mencapai hasil belajar yang optimal.

Pengembangan merupakan suatu proses mendesain pembelajaran secara logis dan sistematis dalam rangka untuk menetapkan segala sesuatu yang akan dilaksanakan dalam proses kegiatan belajar dengan memperhatikan potensi dan kompetensi yang ada pada pada peserta didik (Abdul, 2005).

Nasution (1994:25) memberi pendapat bahwa belajar adalah suatu kegiatan untuk mengatur atau mengelola lingkungan dengan cara yang sebaik-baiknya dan untuk berhubungan dengan peserta didik sehingga terjadi proses yang dinamakan belajar. Sagala (61:2009) mengartikan pembelajaran sebagai pembelajaran siswa dengan menggunakan prinsip-prinsip pedagogis dan teori belajar yang dijadikan tolak ukur dalam keberhasilan akademik.

Modul merupakan salah satu media pembelajaran yang bisa digunakan untuk menunjang kegiatan pendidikan dan pembelajaran. Konten dalam modul ini mencakup konten yang diperlukan untuk menguasai kemampuan. Sangat disarankan untuk mengembangkan kapasitas dalam satu modul, tetapi dengan mempertimbangkan karakteristik spesifik, luas dan kompleksitas kapasitas, dimungkinkan juga untuk mengembangkankapasitas dalam beberapamodul. Abdul (2009: 176) mengartikan modul harus mendeskripsikan keterampilan dasar yang akan dicapai siswa, disajikan dengan bahasa yang baik dan menarik, serta disertasi ilustrasi.

Pelaksanaan pembelajaran PjBL memberikan peluang kepada siswa untuk berfikir kritis dan mengembangkan kreativitasnya dengan merumuskan inisiatif untuk menghasilkan produk nyata berupa barang atau jasa. Kegiatan ini akan memberikan pemahaman baru kepada siswa dengan mengajukan pertanyaan tentang mengapa, kapan, dan bagaimana peristiwa dan keterampilan terkait muncul, (Bransford et al., 2006:23)..

\section{Metode}

Peneitian ini merupakan jenis Penelitian R\&D dimana, langkah yang dapat menjelaskan semua kegiatan ketika mengupgrade produk saat ini atau menciptakan produk baru yang berbeda dari sebelumnya merupakan pengertian dari pemahaman penelitian dan pengembangan (R\&D) (Sugiyono, 2012:407). Menurut Sadiman (2009:164) (R\&D) didefinisikan sebagai proses atau fase yang dapat mengupgrade produk baru atau meningkatkan produk yang sudah ada. Ini bisa dijelaskan, produk ini tidak berupa benda atau perangkat keras (hardware) seperti penunjang pembelajaran pada modul ini diruang kelas dan bengkel, tetapi juga berupa perangkat lunak (software) seperti program komputer untuk pengolahan data dan pembelajaran di kelas.

Pada penelitian ini menggunakan model pengembangan ADDIE. Model ADDIE dipromotori oleh Dick dan Carry (1996) untuk memperbaharui sistem pembelajaran. Pada model ADDIE memiliki tahapan yakni, analisis, desain, pengembangan, implementasi, dan evaluasi. Tahap-tahap model pengembangan ADDIE dapat dirinci sebagai berikut: 


\section{Analysis (penganalisaan)}

Merupakan proses pendefinisian tentang yang akan dipelajari siswa, oleh karena itu peneliti harus memahami serangkaian kegiatan, antara lain melakukan penganalisaan kebutuhan, penganalisaan mata pelajaran dan analisis karakteristik dari para peserta didik.

\section{Analisis Kebutuhan}

Pada tahap ini, Anda akan mengetahui perangkat pembelajaran yang dirasa perlu dikembangkan untuk memfasilitasi peserta didik. Analisis pengembangan perangkat pembelajaran dilakukan dengan mengkaji dan mendiskusikan referensi yang harus diperhatikan dalam penyusunan silabus, RPP, modul, LKS, perangkat pengujian hasil belajar, dan perangkat proyek untuk mengklasifikasikannya sesuai dan sangat bermanfaat sebagai Alat belajar yang bagus.

Penganalisaan berpedoman pada analisis hasil penganalisaan mata pelajaran dan karakteristik peserta didik, karena penganalisaan juga merupakan aspek utama dalam mengembangkan perangkat pembelajaran. Selain perangkat pembelajaran, model pembelajaran proyek yang menjadi dasar perangkat yang akan dikembangkan juga dianalisis, sehingga diperoleh perangkat pembelajaran proyek untuk mata pelajaran TIK.

\section{Analisis Kurikulum}

Tahap ini mempertimbangkan karakteristik kurikulum yang dipakai. Hal ini karena perangkat pembelajaran yang dikembangkan dilakukan untuk memenuhi persyaratan kurikulum mereka. Langkah selanjutnya adalah mempertimbangkan $\mathrm{KD}$ dan mengembangkan indeks prestasi belajar.

3. Analisis Karakteristik Peserta Didik

Analisis sifat peserta didik dilakukan melalui kajian teoritis yang relevan, wawancara dengan instruktur TIK, dan observasi selama proses pembelajaran. Analisa ini digunakan untuk melihat lebih dekat keadaan mental dan fisik siswa yang memakai perangkat pembelajaran tes. Hasil analisis ini akan digunakan sebagai acuan menyusun dan mengembangkan modul pembelajaran.

\section{Design (desain)}

Tahap ini, peneliti mendisain modul pembelajaran dengan cara menetapkan tujuan pembelajaran umum dan khusus. Ini juga mengembangkan item tes atau pertanyaan untuk mengukur tingkat pencapaian tujuan siswa yang ditetapkan oleh tingkat kemajuan mereka, dan pada akhirnya memperbaharui strategi pembelajaran. $\mathrm{PjBL}$ juga dirancang dengan melihat prinsip-prinsip disain pesan untuk melibatkan peserta didik. Pada tahap ini juga ditentukan komponen yang membentuk perangkat pembelajaran berupa silabus, modul dan lembar kerja. Selain itu, peralatan telah diperiksa oleh ahli materi dan ahli media.

\section{Development (pengembangan)}

Langkah ini, menyiapkan modul pembelajaran untuk memenuhi spesifikasi perangkat pembelajaran yang diperbaharui. Hal ini bertujuan untuk mengembangkan modul yang memenuhi materi dan tujuan yang disajikan pada pembelajaran dan situasi belajar lainnya yang mendorong proses dalam pembelajaran. Pada tahap ini juga dikembangkan modul pembelajaran berbasis proyek, berdasarkan hasil validasi instruktur dan revisi produk oleh pakar. Tahapan pengembangannya adalah sebagai berikut:

\section{Pengembangan modul}

Modul pembelajaran dibangun berdasarkan prinsip pengembangan modul, termasuk analisa kebutuhan, desain dan perbaharuan modul, implementasi, evaluasi, evaluasi dan verifikasi,dan penjaminan mutu. Pengembangan desain modul dilakukan secara bertahap yaitu penentuan strategi dan media pembelajaran, pembuatan modul dan pengembangan alat evaluasi. Oleh karena itu, modul dibangun berdasarkan desain yang telah ditentukan.

\section{Pengembangan Perangkat}

Dalam pengembangan Perangkat perlu memperhatikan: 1) menganalisa silabus, 2) menganalisa materi pelajaran, 3) memilih tujuan dan 4) mengembangkan kegiatan pembelajaran. 


\section{Pengembangan jobsheet}

Dalam pengembangan jobsheet dapat dilakukan diantaranya: 1) analisa kurikulum, 2) menyusun jobsheet, 3) memilih judul job dalam jobsheet, dan 4) menulis jobsheet

\section{Pengembangan Instrumen Penilaian dan Angket Respon Guru}

Pada instrumen penilaian, akan dikembangkan 2 buah instrumen penilaian, yaitu instrumen penilaian tes hasil belajar aspek kognitif dan instrumen penilaian proyek.

\section{Validasi Ahli}

Hal ini dilakukan oleh guru ahli dan guru TIK yang menguji keefektifan desain produk dan mendapatkan saran dan kritik dari verifier terhadap produk yang dikembangkan. Juga, dapatkan pernyataan tentang kepraktisan dan kelayakan produk yang sedang dikembangkan.

\section{Revisi}

Tinjau produk dan instrumen setelah diverifikasi. Komentar-komentar tersebut disesuaikan berdasarkan rekomendasi para ahli yang kompeten pada bidangnya masing-masing.

\section{Implementation (implementasi)}

Terdiri dari silabus, RPP, modul, perangkat tersebut diujicobakan secara eksklusif di sekolah yang ditentukan di lokasi penelitian setelah perangkat pembelajaran dinyatakan efektif. Pada tahap ini dilakukan pengujian hasil belajar kognitif (pengetahuan) dan tes teknis siswa (proyek) untuk mengetahui keefektifan modul yang dikembangkan. Setelah itu,instruktur juga membuat jawaban pertanyaan dengan prosedur berikut.

\section{Evaluation (evaluasi)}

Pada tahap evaluasi, perancang mengevaluasi isi/materi media pembelajaran yang dikembangkan dan produk pengembangannya, termasuk evaluasi keefektifan dan keberhasilan media yang dikembangkan. Pada langkah ini, pengembang menggunakan pengembangan perangkat pembelajaran berbasis proyek untuk membedakan data dari pertanyaan jawaban instruktur setelah pembelajaran selesai dinyatakan berhasil..

\section{Hasil dan Pembahasan}

Hasil penelitian ini adalah untuk mengetahui validitas, praktikalitas, dan efektivitas modul pembelajaran berbasis Project Based Learning pada mata pelajaran TIK kelas IX di SMP Negeri 9 Padang. Pengembangan modul ini dilakukan menggunakan model pengembangan $A D D I E$ melalui empat tahapan pengembangan media yaitu: a) Analisis b)Tahap pendefinisian (Define); b) Tahap Perancangan (Design); c) Tahap Pengembangan (Implementation); d) Tahap Evaluasi (Evaluation).

Modul Pembelajaran Berbasis Project Based Learning pada mata Pelajaran TIK menggunakan Aplikasi Geschool digunakan sebagai alternatif untuk mendukung pembelajaran daring pada mata pelajaran Teknologi Informasi dan Komunikasi. Modul ini telah melalui tahap uji coba validitas, praktikalitas dan efektivitas. Pada uji coba validitas dilakukan dengan cara meminta pendapat para ahli yaitu ahli media dan ahli materi terhadap modul yang dikembangkan. Uji coba praktikalitas dilakukan dengan meminta pendapat kepada guru mata pelajaran Teknologi Informasi dan komunikasi dan siswa melalui angket yang diambil menggunakan Google Form . Sedangkan uji efektivitas dilakukan dengan cara melihat perbandingan antara hasil belajar siswa sebelum menggunakan modul pembelajaran berbasis Project Based Learning dengan hasil belajar siswa setelah menggunakan modul pembelajaran berbasis Project Based learning. Pembahasan tentang hasil penelitian secara detail dan lengkap dipaparkan sebagai berikut.

\section{Tahap Analisis}

Jika dianalisis, pada penelitian ini yang menjadi subjek adalah siswa SMPN 9 Kota Padang karena selama pembelajaran daring nilai siswa cenderung rendah. Karena siswa hanya diberikan materi dan soal menggunakan geschool, yang terkadang terkendala masalah teknis seperti, kehabisan pulsa, jaringan yang bermasalah sehingga pembelajaran tidak optimal dan tidak berjalan dengan baik. Pada tahap ini dikumpulkan informasi yang mendukung penelitian ini. 


\section{Validitas Media Pembelajaran}

Data yang akan dipakai untuk mengukur validitas media pembelajaran berbasis Project Based Learning ini adalah data yang didapat melalui masukan dari validator menggunakan angket. Peneliti memberikan angket kepada lima orang validator yang memvalidasi media yang dikembangkan. Validator pertama, kedua dan ketiga melakukan validasi terhadap desain modul pembelajaran yang dirancang. Sedangkan validator ketiga, keempat dan kelima melakukan validasi terhadap materi pada media yang dikembangkan.

Tabel $1<$ Data Validator $>$

\begin{tabular}{clll}
\hline No. & \multicolumn{1}{c}{ Nama Validator } & \multicolumn{1}{c}{ Penilaian } & \multicolumn{1}{c}{ Aspek yang divalidasi } \\
\hline 1. & Prof. Dr. Wakhinuddin & Dosen FT-UNP & Desain Media Pembelajaran \\
Wawan Purwanto, S. Pd., M., & Dosen FT-UNP & Desain Media Pembelajaran \\
3. & $\begin{array}{l}\text { T., Ph. D. } \\
\text { Dony Novaliendry, S. Kom., M. }\end{array}$ & Dosen FT-UNP & Desain Media Pembelajaran \\
Kom. & $\begin{array}{l}\text { Ikhsan Wahyudi, S.Pd } \\
\text { R. }\end{array}$ & Guru SMP & Materi Pembelajaran teknologi \\
& & Guru SMP & $\begin{array}{l}\text { Informasi dan Komunikasi } \\
\text { Materi Pembelajaran teknologi } \\
\text { Informasi dan Komunikasi }\end{array}$ \\
\hline
\end{tabular}

Validator media pembelajaran, pada modul pembelajaran Berbasis Project Based Learning. Hasil dari penilaian setiap aspek yang diberikan oleh validator kemudian dianalisis menggunakan rumus statistik Aiken's V. Hasil yang diperoleh merupakan nilai validasi terhadap rancangan modul pembelajaran berbasis Project Based Learning yang dihasilkan.

Tabel $2<$ Data Hasil Validitas Ahli Media $>$

\begin{tabular}{cccc}
\hline No. & Validator & Penilaian & Kategori \\
\hline 1. & Validator 1 & 0,93 & Valid \\
2. & Validator 2 & 0,86 & Valid \\
3. & Validator 3 & 0,80 & Valid \\
& Total & $\mathbf{0 , 8 6}$ & Valid \\
\hline
\end{tabular}

Tabel $3<$ Data Hasil Validitas Ahli Materi>

\begin{tabular}{cccc}
\hline No. & Validator & Penilaian (\%) & Kategori \\
\hline 1. & Validator 1 & $86,5 \%$ & Valid \\
2. & Validator 2 & $90 \%$ & Valid \\
& Rata-rata & $\mathbf{8 8 , 2 5 \%}$ & Valid \\
\hline
\end{tabular}

Sumber: Pengolahan Data Peneliti

Berdasarkan tabel 4.4 menunjukan hasil penilaian dari validator untuk modul pembelajaran berbasis Project Based Learning, pada validator 1 mendapatkan hasil validitas dengan nilai 88,25\%, Validator 2 mendapatkan hasil validitas dengan nilai $90 \%$. Secara keselurukan penilaian uji validasi materi terhadap media pembelajaran berbasis Project Based Learning sebesar 88,25\%, sehingga modul pembelajaran berbasis Project Based Learning tersebut bisa dikatakan valid digunakan untuk pembelajaran Teknologi Informasi dan Komunikasi.

\section{Simpulan}

Dalam penelitian pengembangan ini menghasilkan modul pembelajaran Projec Based Learning pada mata pelajaran TIK. Berdasarkan hasil pengembangan da uji coba produk.

1. Modul pembelajaran berbasis Project yang dihasilkan dinyatakan oleh para ahli sebagai media yang valid sehingga dapat digunakan sebagai media pembelajaran, dengan rata-rata validitas media sebesar 0,86 dan validitas materi sebesar 0,88 .

2. Modul pembelajaran berbasis Project Based Learning yang dihasilkan dinyatakan sebagai media yang sangat praktis yang direspon oleh guru dan siswa, dengan nilai kepraktisan dari respon guru sebesar $85,42 \%$ dan respon siswa sebesar $85,11 \%$. 


\section{Referensi}

Borg \& Gall. 1983. Education Research. New York: Allyn and Bacon.

Nasution, M.A. 2008. Berbagai Pendekatan Dalam Proses Belajar Mengajar. Jakarta: Bumi Aksara.

Sagala, Syaiful. 2009. Manajemen Strategik dalam Peningkatan Mutu Pendidikan. Bandung: Alfabeta.

Sugiyono. 2012. Metode Penelitian Pendidikan; Pendekatan Kuantitatif, Kualitatif, dan R\&D. Bandung: Alfabeta.

Susanto, A, 2016. Teori Belajar dan pembelajaran sekolah di dasar, Jakarta Kencana

Sani, M. (2015). Pengembangan Modul Pembelajaran Berbasis Proyek Pada Mata Kuliah Pemeliharaan dan Perbaikan Mesin Listrik. Jurnal Pendidikan Teknik Elektro, 04(01), 259-267. 